\title{
Quality of second-crop corn according to the period between harvest and drying
}

\author{
José C. de Andrade ${ }^{1}$, André L. D. Goneli ${ }^{1}$, Cesar P. Hartmann Filho', \\ Thalita M. S. de Azambuja ${ }^{1} \&$ Valdenise C. Barboza ${ }^{1}$
}

${ }^{1}$ Universidade Federal da Grande Dourados/Faculdade de Ciências Agrárias. Dourados, MS. E-mail: joseandradecarlos@hotmail.com; andregoneli@ufgd.edu.br; cphartmann21@hotmail.com (Corresponding author); thalitaazambuja@gmail.com; valdenise.barboza@gmail.com

\section{Key words:}

Zea mays L.

physical and sanitary quality of grains

post-harvest

\begin{abstract}
A B S T R A C T
The objective of this study was to evaluate the quality of second-crop corn harvested with different moisture contents as a function of time before drying. The corn grains were harvested with moisture content of $28.5,22.4,21$ and $19 \%$, and submitted to a temporary storage for ten days, simulating the time between harvesting and drying. Quality was subsequently evaluated every two days, based on the commercial classification of the grains, sanity test and dry bulk density. The results showed that: the increase in moisture content at harvest affects the physical and sanitary quality of second-crop corn, and this effect is aggravated over time; the moisture content of $19 \%$ is the one that least affects grain quality during the ten days of temporary storage.
\end{abstract}

\section{Palavras-chave:}

Zea mays L.

qualidade física e sanitária de grãos pós-colheita

\section{Qualidade do milho segunda safra em função do tempo entre a colheita e a secagem}

\begin{abstract}
R E S U M O
O presente trabalho foi realizado com o objetivo de avaliar a qualidade do milho segunda safra colhido com diferentes teores de água em função do tempo até a secagem. Os grãos de milho foram colhidos com teores de água de aproximadamente 28,$5 ; 22,4 ; 21$ e $19 \%$, e submetidos a um armazenamento temporário durante dez dias, simulando o tempo entre a colheita e a secagem. A qualidade foi avaliada por meio da classificação comercial dos grãos, do teste de sanidade e da massa específica aparente de matéria seca a cada dois dias subsequentes. Com base nos resultados obtidos, conclui-se que: o aumento do teor de água de colheita influencia negativamente a qualidade física e sanitária do milho produzido na segunda safra, sendo este efeito agravado com o tempo; o teor de água de colheita de $19 \%$ é o que menos afeta a qualidade dos grãos durante os dez dias de armazenamento temporário.
\end{abstract}




\section{INTRODUCTION}

In the current situation of corn, especially second-crop corn, the area relative to post-harvest and its discrepancy in the storage sector can be seen as one of the main problems, because implications caused by them affect parameters directly related to the commercial and industrial sector (Kussano \& Batalha, 2012). One example of this refers to increasing qualiquantitative losses observed every year, because the harvested material temporarily remains stored in the trucks, vulnerable to the attack of pathogens and intensification of deterioration processes. Since the uncontrolled environmental conditions and oscillations of temperature and relative humidity directly interfere with the metabolic activity of the product and of the microflora associated with it, the increase in the consumption of dry matter as well as the increment in the values of rotten, moldy and germinated grains are commonly observed (Del Campo et al., 2014; Coradi et al., 2015, 2016).

In Brazil, given the difficult interaction between the field and the commercial sector, the static capacity became insufficient to meet the production (Oliveira Neto et al., 2015; Nascimento et al., 2016). The amount of corn produced in the second crop required about $30 \%$ of the national storage capacity in the 2015/2016 season; however, the occupation by about $62 \%$ of soybean, $17 \%$ of first-crop corn and $7 \%$ of rice exceeded the current static capacity (CONAB, 2016).

In this context, the search for studies capable of estimating the possible losses in corn quality between harvest and drying are of extreme relevance, because the domain related to logistics uses data to reduce costs and losses. Hence, factors such as time and moisture content at harvest are important, for being related to the deterioration potential of the material during the entire post-harvest stage and, particularly, to the value associated with it

Thus, the present study aimed to evaluate second-crop corn harvested with different moisture contents as a function of the time until the drying.

\section{Material AND Methods}

This study was carried out in two steps: the first one consisted in the grain production stage and the second one in the temporarily storage and evaluation of grain quality. Production occurred between February and July 2014, at the

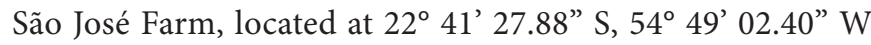
and $409 \mathrm{~m}$ of altitude, in the municipality of Caarapó, MS. The temporary storage was conducted on the farm, while the qualitative evaluation was performed at the Laboratory of PreProcessing and Storage of Agricultural Products, of the Faculty of Agricultural Sciences (FCA) of the Federal University of Grande Dourados (UFGD), located in the municipality of Dourados, MS.

The single-cross corn hybrid used to obtain the material was 'BG 7061H', cultivated in no-tillage system. Tillage consisted only in the procedures of desiccation, using 1,680 $\mathrm{g}$ a.i. ha ${ }^{-1}$ of the herbicide glyphosate, seven days before sowing. Fertilization was applied simultaneously to sowing, using $300 \mathrm{~kg} \mathrm{ha}^{-1}$ of the fertilizer formulation 08-20-20 (N-P-K), 30 days after seedling emergence, applying $150 \mathrm{~kg} \mathrm{ha}^{-1}$ of urea for an expected yield of $6 \mathrm{t}$ of corn ha $\mathrm{a}^{-1}$ (Sousa \& Lobato, 2004). The seeds were treated with insecticide (Thiamethoxam $-3 \mathrm{~g} \mathrm{~kg}$ of seeds $^{-1}$ ) and

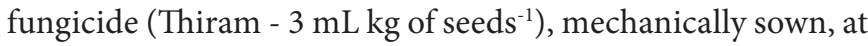
spacing of $0.50 \mathrm{~m}$ between rows and density of 3 seeds $\mathrm{m}^{-1}$, for a final population of 60,000 plants $\mathrm{ha}^{-1}$.

Grains were mechanically harvested using a TC 57 harvester, whose platform has eight lines. The moisture contents of harvest were 28.5, 22.4, 21 and 19\% (w.b.). To simulate the transport time from harvest to drying, each lot was placed in a wooden box, which remained covered with plastic canvas (Vinolona), emulating the bed of a truck. The temporary storage lasted ten days and the tests were conducted immediately after harvesting and then every two days $(0,2$, $4,6,8$ and 10 days), totaling six periods of evaluation. Each box was $1 \mathrm{~m}$ wide, $1 \mathrm{~m}$ high and $2 \mathrm{~m}$ long $\left(2 \mathrm{~m}^{3}\right)$, and stored approximately $1,500 \mathrm{~kg}$ of corn. Fifteen replicates were used for each treatment.

During the pre-established intervals, the values of temperature and relative air humidity were determined based on data from a weather station. The moisture content of the product was determined through the gravimetric method in an oven at $105 \pm 3{ }^{\circ} \mathrm{C}$, for $24 \mathrm{~h}$, in two replicates (Brasil, 2009b). The behavior of grain mass temperature was monitored with a Six's thermometer, connected to a probe positioned in four points of the box, for a period of $5 \mathrm{~min}$ in each point. Grain quality evaluation was based on the commercial classification. Corn grains were classified according to the Normative Instruction No 60 of the Ministry of Agriculture, Livestock and Supply (MAPA), published on the Government Gazette of December 23, 2011 (Brasil, 2011).

Analyses were made regarding the sanitary state, identifying and quantifying fungi. Fungal identification and quantification were performed through the filter paper method with freezing, using 16 subsamples of 25 grains (Brasil, 2009a). The grains were distributed inside plastic boxes (Gerbox) on a layer of three sheets of filter paper moistened with distilled water, in a volume equivalent to 2.5 times the weight of the dry paper. First, the boxes were stored for $24 \mathrm{~h}$ in an incubation chamber (B.O.D.), at temperature of $20 \pm 2{ }^{\circ} \mathrm{C}$, with photoperiod of $12 \mathrm{~h}$ of light/12 $\mathrm{h}$ of dark. Then, the boxes were frozen in a freezer, for $24 \mathrm{~h}$. After this period, the boxes were again stored in incubation chamber at temperature of $20 \pm 2{ }^{\circ} \mathrm{C}$, with photoperiod of $12 \mathrm{~h}$ of light/12 h of dark, for more five days. After seven days of incubation, the seeds were examined in a stereoscopic microscope to identify and quantify the fungi, observing their reproductive structures (Barnett \& Hunter, 1998).

Dry bulk density was obtained disregarding the moisture content of the bulk density (Eq. 1), which was determined on a test weight scale, using a cylindrical container with capacity for $0.25 \mathrm{~L}$, in 10 subsamples.

$$
\mathrm{DBD}=\mathrm{BD}\left(1-\frac{\mathrm{W}}{100}\right)
$$

where:

DBD - dry bulk density, $\mathrm{kg} \mathrm{m}^{-3}$; 
BD - bulk density, $\mathrm{kg} \mathrm{m}^{-3}$; and,

W - grain moisture content, \% (w.b.).

The experiment was set in a $4 \times 6$ split-plot scheme, with four moisture contents of harvest in the plots and six evaluation periods, referring to the transport time between harvest and drying, in the subplots, in a completely randomized design. To evaluate the latent effect of the moisture contents of harvest, the data were subjected to polynomial regression analysis. The models were selected considering the magnitude of the coefficient of determination $\left(\mathrm{R}^{2}\right)$, significance of the regression by $\mathrm{F}$ test and the studied biological phenomenon.

\section{Results AND Discussion}

Figure 1 shows the variations of temperature and relative humidity along the experiment. Given these circumstances, the mean values of temperature and relative humidity during the temporary storage were $18{ }^{\circ} \mathrm{C}$ and $72 \%$, while the maximum and minimum values were $31^{\circ} \mathrm{C}$ and $87 \%$, and $6{ }^{\circ} \mathrm{C}$ and $38 \%$, respectively.

According to Table 1, due to grain hygroscopicity, increments in the moisture contents were observed during the storage, because the uncontrolled conditions of temperature and relative air humidity lead to the occurrence of sorption phenomena (Hartmann Filho et al., 2016). Hence, increases of approximately 9.7, 5.5, 5.7 and 5 percent points were observed in corn grains harvested with moisture contents of 28.5, 22.4, 21 and 19\%, respectively.

Based on Table 1, it is possible to note a similarity between the treatments harvested with moisture contents of 22.4 and $21 \%$, which showed smaller difference regarding the final

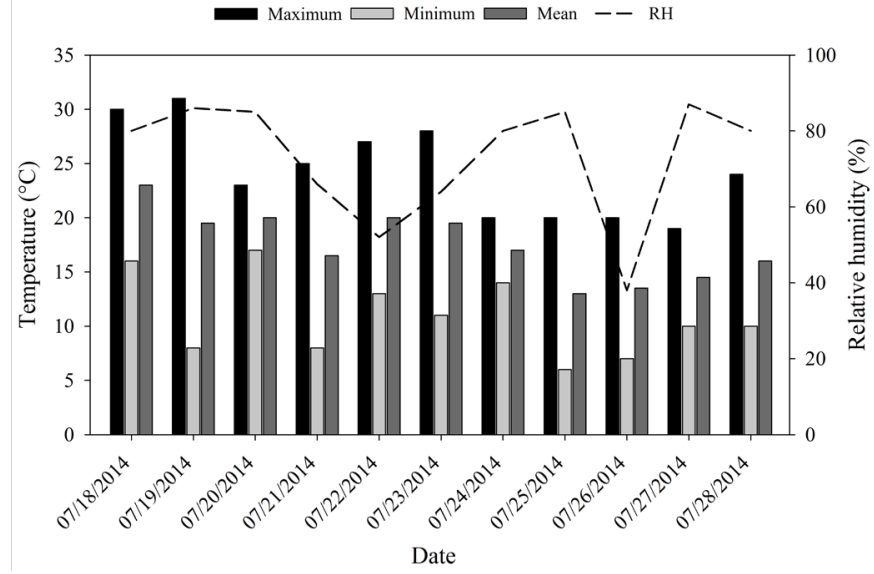

Figure 1. Daily means of temperature and relative air humidity, during 10 days of temporary storage of corn grains in uncontrolled environment

Table 1. Mean values of moisture content (\% w.b.) of corn grains as a function of the moisture content at harvest and waiting time

\begin{tabular}{ccccccc}
\hline Moisture content & \multicolumn{7}{c}{ Waiting time (days) } \\
\cline { 2 - 7 } at harvest (\% w.b.) & $\mathbf{0}$ & $\mathbf{2}$ & $\mathbf{4}$ & $\mathbf{6}$ & $\mathbf{8}$ & $\mathbf{1 0}$ \\
28.5 & 28.5 & 30.7 & 31.4 & 31.5 & 34.3 & 38.2 \\
22.4 & 22.4 & 22.5 & 24.4 & 24.7 & 25.4 & 27.9 \\
21.0 & 21.0 & 22.3 & 22.4 & 23.4 & 25.2 & 26.7 \\
19.0 & 19.0 & 20.4 & 21.3 & 22.0 & 22.0 & 24.0 \\
\hline
\end{tabular}

moisture content, equal to $1.2 \%$. In addition, this fact possibly occurred because grains harvested with moisture content of $19 \%$ absorbed $3.5 \%$ more of water, compared with those harvested with moisture content of $24 \%$.

Despite that, in general, as the moisture content at harvest increased, there were higher moisture contents after the ten days of temporary storage (Table 1). Therefore, this fact eventually suggested that materials with higher moisture contents, for being with higher metabolic activity (respiratory process), usually have their interaction with the environment facilitated, thus promoting water absorption (Mahjabin \& Abidi, 2015). In addition, since the high moisture content of the material intensifies its respiratory activity, which produces water as a product, most likely it is eventually re-absorbed in situations like this, promoting increments compared with the initial moisture content (Hartmann Filho et al., 2016).

Another factor that may have collaborated to the increase in the final moisture content of the grains, according to the increment in the moisture content at harvest, was the fact that corn grains harvested with high moisture content usually have higher percentage of impurities and, since this material has high water retention capacity, it eventually increases the moisture contents of the product (Marques et al., 2012).

As to the temperature of the mass of grains, it increased according to the increment in the moisture contents of harvest and along the temporary storage period (Table 2). Thus, the fact that grains harvested with higher moisture contents have high metabolic activity could be confirmed, since the heating of the mass of grains is one of the main characteristics of the high respiratory activity (Nascimento \& Queiroz, 2011).

Therefore, since the respiratory process involves the consumption of reserves and oxygen, and produces water and $\mathrm{CO}_{2}$ as byproducts, it was possible to infer that one of the forms of energy dissipation of the system was the production of heat, which led to the increase in the temperature of the mass of stored grains. This fact was more accentuated in the grains harvested with higher moisture contents, because they showed greater heating in their mass, along the temporary storage. Examples of that were the increases of $12,10,8$ and $3{ }^{\circ} \mathrm{C}$ at the end of the ten days, in grains harvested with moisture contents of 28.5, 22.4, 21 and 19\%, respectively (Table 2).

The action of the studied factors was evidenced by the classification of the corn grains, which showed a difference in the percentages of rotten and germinated grains (Figure 2).

With the increment in the moisture content at harvest and temporary storage time, there was an increase in the percentages of both rotten and germinated grains, evidencing a reduction in the quality of the product (Figure 2). This behavior was due to the joint action of the four main deteriorating factors, moisture content of the material, temperature and

Table 2. Mean values of temperature $\left({ }^{\circ} \mathrm{C}\right)$ of corn grains as a function of the moisture content at harvest and waiting time

\begin{tabular}{ccccccc}
\hline Moisture content & \multicolumn{7}{c}{ Waiting time (days) } \\
\cline { 2 - 7 } at harvest (\% w.b.) & $\mathbf{0}$ & $\mathbf{2}$ & $\mathbf{4}$ & $\mathbf{6}$ & $\mathbf{8}$ & $\mathbf{1 0}$ \\
28.5 & 38.0 & 40.0 & 46.0 & 50.0 & 50.0 & 50.0 \\
22.4 & 34.0 & 36.0 & 40.0 & 41.0 & 44.0 & 44.0 \\
21.0 & 34.0 & 35.0 & 38.0 & 40.0 & 40.0 & 42.0 \\
19.0 & 34.0 & 35.0 & 36.0 & 36.0 & 37.0 & 37.0 \\
\hline
\end{tabular}



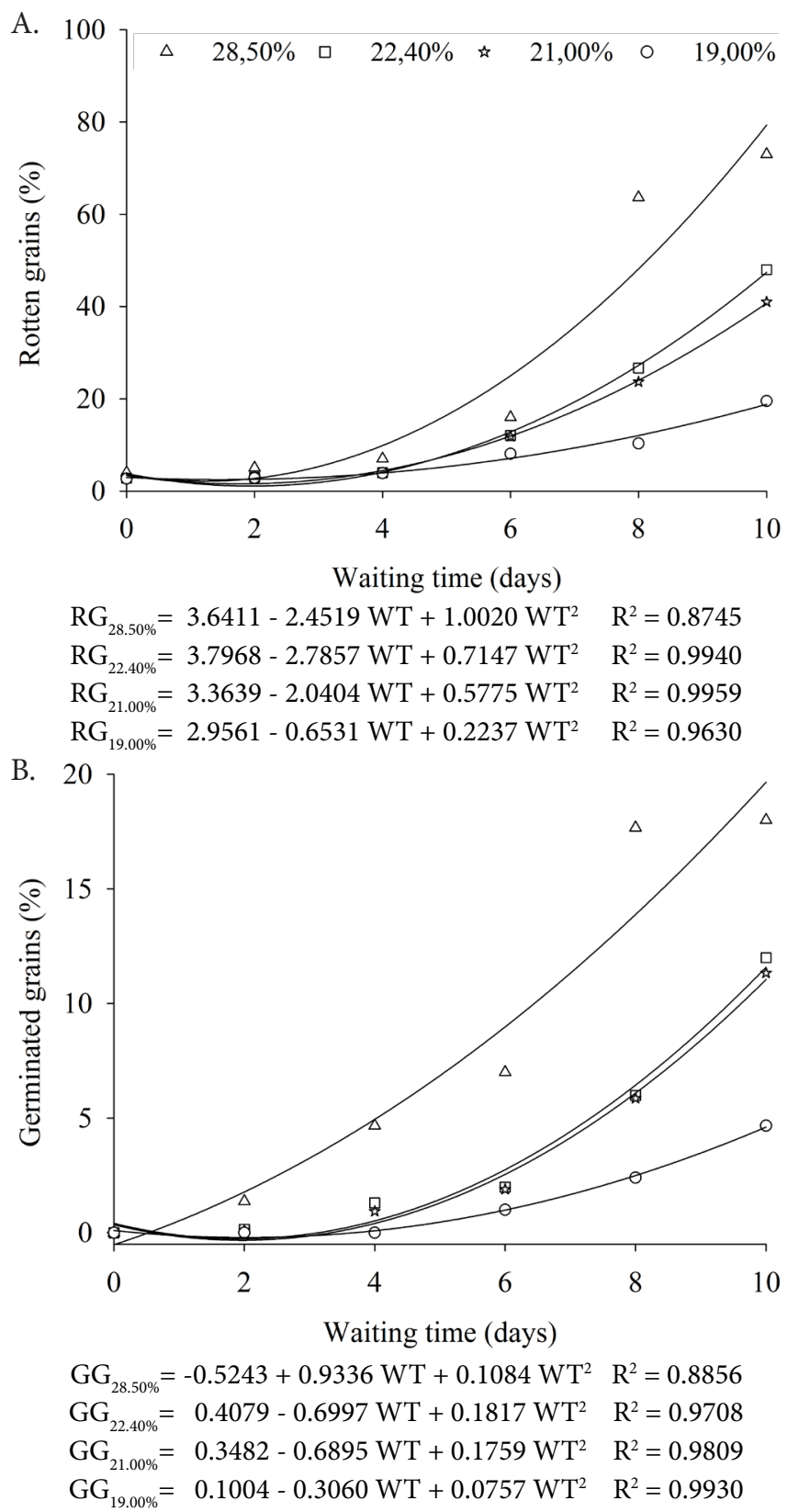

Figure 2. Percentages of rotten grains (A) and germinated grains (B) as a function of the moisture content at harvest and waiting time

A.

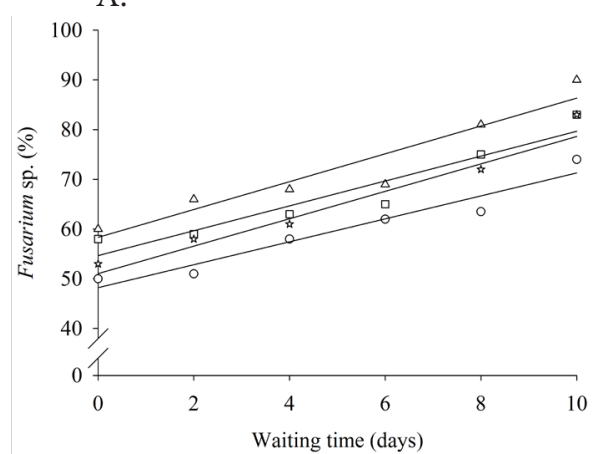

B.

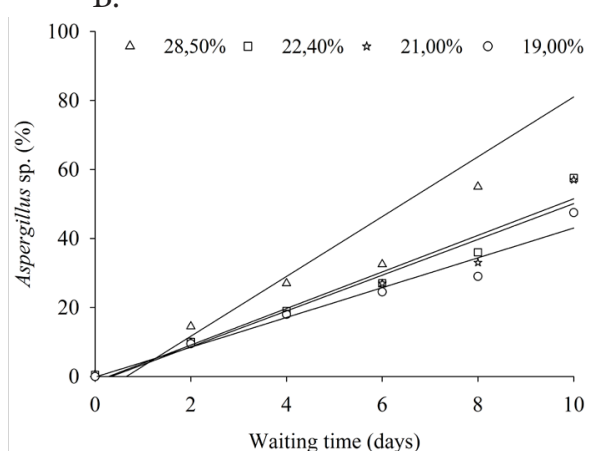

relative humidity of the environment and time, because their interaction intensifies the deterioration and makes germination viable, directly interfering with the classification (Paraginski et al., 2015).

In addition, it was possible to observe, based on the classification and on the increase in the moisture content at harvest, that the lots were different regarding their classification in types with respect to the time (Figure 2). The lot harvested with moisture content of $28.5 \%$, for instance, three days after harvest could already be defined as off-type, while for the others, such characterization could be made only on the fifth day. This occurred because the lot has a percentage of rotten grains superior to the maximum limit accepted (5\%), which, besides compromising the marketing, can interfere with the discounts applied by the buyer.

It was possible to observe that, despite harvesting the product with relatively lower moisture content (19\%), its aptitude to undergo deterioration processes is still present when stored in an inadequate environment, since the variations of temperature and relative humidity drive deterioration intensity, moisture content allows the occurrence of the respiratory process, and time can accentuate such deleterious activity (Bento et al., 2012; Coradi et al., 2016).

For the sanity test, it was possible to note an increase in the percentage of contamination by fungi with the increment of both factors, and the infestation level varied from 0 to $86 \%$ (Figure 3).

Immediately at harvest, fungi of the genera Fusarium sp. and Penicillium sp. were present, thus evidencing a contamination already in the pre-harvest stage of the product (Figures $3 \mathrm{~A}$ and C). However, the latent linear potentiation allowed to confirm that, due to the conditions along the storage, the reproduction and, consequently, infestation by both genera was facilitated and even reached, for instance, 86 and $61 \%$ on the tenth day, for the genera Fusarium sp. and Penicillium sp., respectively, in grains harvested with moisture content of $28.5 \%$.

Although contamination was not identified immediately at harvest, the presence of the genus Aspergillus sp. could be noted during the temporary storage, because it was identified one day after the storage of the product. In addition, since

$\mathrm{FS}_{28.50 \%}=58.3333+2.8000 \mathrm{WT} \quad\left(\mathrm{R}^{2}=0.8758\right) \mathrm{AS}_{28.50 \%}=-5.6905+8.6714 \mathrm{WT} \quad\left(\mathrm{R}^{2}=0.8804\right) \mathrm{PN}_{28.50 \%}=25.3333+3.5500 \mathrm{WT} \quad\left(\mathrm{R}^{2}=0.7970\right)$

$\mathrm{FS}_{22.40 \%}=54.6667+2.5000 \mathrm{WT} \quad\left(\mathrm{R}^{2}=0.8780\right) \quad \mathrm{AS}_{22.40 \%}=-1.5000+5.3000 \mathrm{WT} \quad\left(\mathrm{R}^{2}=0.9534\right) \mathrm{PN}_{22.40 \%}=15.3571+4.7786 \mathrm{WT} \quad\left(\mathrm{R}^{2}=0.7651\right)$

$\mathrm{FS}_{21.00 \%}=51.0476+2.7571 \mathrm{WT} \quad\left(\mathrm{R}^{2}=0.8758\right) \mathrm{AS}_{21.00 \%}=-1.7619+5.1857 \mathrm{WT} \quad\left(\mathrm{R}^{2}=0.9353\right) \mathrm{PN}_{21.00 \%}=13.5476+5.1571 \mathrm{WT} \quad\left(\mathrm{R}^{2}=0.8770\right)$

$\mathrm{FS}_{19.00 \%}=48.2143+2.3071 \mathrm{WT} \quad\left(\mathrm{R}^{2}=0.9236\right) \mathrm{AS}_{19.00 \%}=-0.1905+4.3214 \mathrm{WT} \quad\left(\mathrm{R}^{2}=0.9518\right) \mathrm{PN}_{19.00 \%}=9.5476+4.8071 \mathrm{WT} \quad\left(\mathrm{R}^{2}=0.7611\right)$

Figure 3. Percentage of infestation by Fusarium sp. (A) Aspergillus sp. (B) and Penicillium sp. (C), as a function of the moisture content at harvest and waiting time 
this genus has high multiplication capacity, there was a linear increase in its infestation level, and this latent effect was more accentuated as the moisture content at harvest increased, because the multiplicative coefficients of the fitted equations were higher as the factor increased (Figure 3B).

This fact resulted from the high moisture content of the material, which initially favored the development of the microflora, providing conditions for the development of Aspergillus sp. fungi, since corn grains stored with high moisture contents, above $20 \%$, facilitated the development of the microorganisms associated with them, because their respiratory activity promotes significant increases in parameters favorable to such increment, such as moisture content and temperature (Coradi et al., 2015; Stefanello et al., 2015).

According to Tsedaley \& Adugna (2016), the genera Fusarium sp., Aspergillus sp. and Penicillium sp. are the ones occurring with higher frequency in corn, because of their high capacity of association with the grains. In addition, as evidenced by the same authors, the presence of these genera in corn samples, of the field infestation level, is highly responsive to conditions in which the material is harvested and subjected after harvest, since the moisture content of the product, as well as the conditions of temperature and relative humidity of the environment and time, are the main conditioning factors limiting their infestation.

In the obtained results, greater ability for development during the temporary storage was observed in the genera Aspergillus sp. and Penicillium sp. compared with Fusarium sp., since the equations fitted to both showed superior multiplicative coefficients (Figure 3). However, as evidenced by Bento et al. (2012), when corn is stored under uncontrolled environmental conditions, also associated with high moisture contents, even genera not characteristic of storage have the capacity to increase their infestation, such as Fusarium sp. Furthermore, according to the same authors, the incidence of the genera Aspergillus sp. and Penicillium sp. in recentlyharvested corn grains is generally low. However, during the storage their multiplication capacity can be potentiated, because their propagation ability occurs even when the material has moisture contents considered as low, like 13\%.

The dry bulk density of corn grains showed a decreasing response as the moisture content increased, and a deleterious linear effect was observed along the temporary storage (Figure 4).

Immediately after harvest, the dry bulk densities found for the moisture contents of harvest of 28.5, 22.4, 21 and 19\% were $481.27,570.54,583.18$ and $597.47 \mathrm{~kg} \mathrm{~m}^{-3}$, respectively (Figure 4). However, due to the latent behavior, at the end of the ten days the values observed for the variable relative to the same moisture contents were 391.0, 466.0, 480.46 and $513.67 \mathrm{~kg} \mathrm{~m}^{-3}$.

Such result occurred immediately after harvest because the high moisture content compromises the arrangement of the material in the container (Araújo et al., 2015). Hence, since a smaller amount of wet product is accommodated in the pre-established volume, a smaller amount of dry matter was determined (Figure 4). The latent effect caused by the interaction between factors on the variable, in turn, evidenced an intensification in the deterioration processes, since it led to loss of dry matter (Figure 4). During the ten days in which

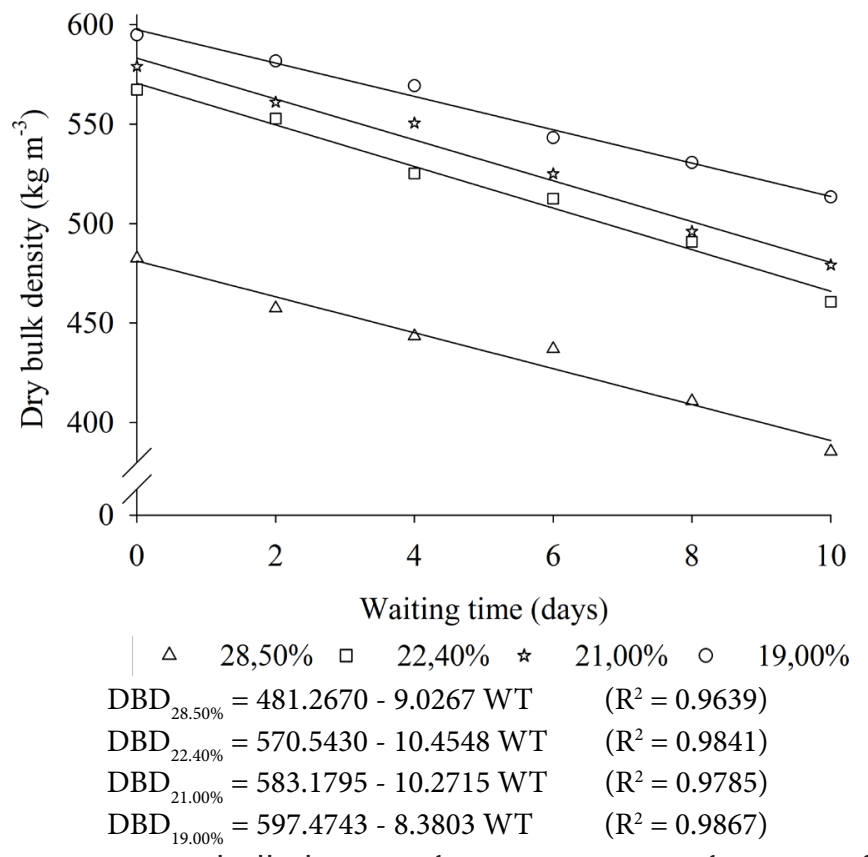

Figure 4. Dry bulk density of corn grains, as a function of the moisture content at harvest and waiting time

the product was stored, losses of dry matter on the order of $19.0,18.5,17.5$ and $14 \%$ were found for grains harvested with moisture contents of 28.5, 22.4, 21 and 19\%, respectively.

Therefore, it is possible to infer that the loss of dry matter was facilitated by the conditions imposed by the studied factors, because the interaction enabled the development of deteriorating circumstances. In this context, the uncontrolled conditions of temperature and relative humidity, associated with the high moisture contents, intensified the respiratory activity of the grains, one of the main contributors to the consumption of reserves after harvest (Hartmann Filho et al., 2016; Ortiz et al., 2016).

As the respiration, the fungi and their infestation also collaborate in the loss of dry matter, since they interfere with the deterioration level of the product, using their reserves, such as proteins, carbohydrates and lipids, for development, making it more susceptible to oscillations of temperature and relative humidity, determinant factors conditioning the respiratory intensity (Coradi et al., 2015; Stefanello et al., 2015).

\section{Conclusions}

1. The increase in moisture content at harvest negatively influences the physical and sanitary quality of second-crop corn grains, and this effect is potentiated with the time of temporary storage.

2. Among the moisture contents of harvest, $19 \%$ is the one that least affects corn quality during the ten days of temporary storage.

\section{ACKnowledgements}

To the Coordenação de Aperfeiçoamento de Pessoal de Nível Superior (Capes) and the Fundação de Apoio ao Desenvolvimento do Ensino, Ciência e Tecnologia do Estado de Mato Grosso do Sul (Fundect), due the financial support for research. 


\section{Literature Cited}

Araújo, W. D.; Goneli, A. L. D.; Orlando, R. C.; Martins, E. A. S.; Hartmann Filho, C. P. Propriedades físicas dos frutos de amendoim durante a secagem. Revista Caatinga, v.28, p.170-180, 2015. https://doi.org/10.1590/1983-21252015v28n419rc

Barnett, H. L.; Hunter, B. B. Illustrated genera of imperfect fungi. 4.ed. St. Paul: American Phytopathological Society, 1998. 218p.

Bento, L. F.; Caneppele, M. A. B.; Albuquerque, M. C. de F. e; Kobayasti, L.; Caneppele, C.; Andrade, P. de J. Ocorrência de fungos e aflatoxinas em grãos de milho. Revista do Instituto Adolfo Lutz, v.71, p.44-49, 2012.

Brasil. Ministério da Agricultura, Pecuária e Abastecimento. Manual de análise sanitária de sementes. Secretaria de Defesa Agrícola. Brasília: MAPA/ACS, 2009a. 200p.

Brasil. Ministério da Agricultura, Pecuária e Abastecimento. Regras para análise de sementes. Secretaria de Defesa Agrícola. Brasília: MAPA/ACS, 2009b. 399p.

Brasil. Ministério da Agricultura, Pecuária e Abastecimento. Instrução Normativa $\mathrm{n}^{\circ} 60$, de 22 de dezembro de 2011. Regulamento Técnico do Milho. Diário Oficial da República Federativa do Brasil, Brasília, 23 dez. 2011, seção 1, n.246, p.3-5.

CONAB - Companhia Nacional de Abastecimento. Acompanhamento da Safra Brasileira-Grãos 2015/2016 (décimo primeiro levantamento). v.3, n.11. Disponível em: <http://www.conab.gov. br/OlalaCMS/uploads/arquivos/16_08_09_12_08_19_boletim_ graos_agosto_2016.pdf >. Acesso em: 25 Ago. 2016.

Coradi, P. C.; Camilo, L. J.; Cunha, F. F.; Pereira, T. L. L.; Alves, C. Z. Alternatives of storage of corn grains for the conditions of the brazilian cerrado. Bioscience Journal, v.32, p.29-40, 2016. https:// doi.org/10.14393/BJ-v32n1a2016-29119

Coradi, P. C.; Lacerda Filho, A. F. de; Chaves, J. B. P.; Mota, T. O. Loss of dry matter in grain corn stored under different conditions and effects on quality. Revista Brasileira de Tecnologia Agroindustrial, v.9, p.1757-1770, 2015. https://doi.org/10.3895/rbta.v9n1.1868

Del Campo, B. G.; Brumm, T. J.; Bern, C. J.; Nyendu, G. C. Corn cob dry matter loss in storage as affected by temperature and moisture content. Transactions of the American Society of Agricultural and Biological Engineers, v.52, p.573-578, 2014.

Hartmann Filho, C. P.; Goneli, A. L. D.; Masetto, T. E.; Martins, E. A. S.; Oba, G. C.; Siqueira, V. C. Quality of second crop soybean submitted to drying and storage. Pesquisa Agropecuária Tropical, v.46, p.267-275, 2016. https://doi.org/10.1590/1983$40632016 \mathrm{v} 4641380$

Kussano, M. R.; Batalha, M. O. Custos logísticos agroindustriais: Avaliação do escoamento da soja em grão do Mato Grosso para o mercado externo. Gestão \& Produção, v.19, p.619-632, 2012. https://doi.org/10.1590/S0104-530X2012000300013
Mahjabin, S. B.; Abidi, A. B. Physiological and biochemical changes during seed deterioration: A review. International Journal of Recent Scientific Research, v.6, p.3416-3422, 2015.

Marques, O. J.; Vidigal Filho, P. S.; Scapim, C. A.; Reche, D. L.; Pricinotto, L. F.; Okumura, R. S. Qualidade comercial de diferentes híbridos de milho em função do teor de água nos grãos durante a colheita. Semina: Ciências Agrárias, v.33, p.911-920, 2012. https:// doi.org/10.5433/1679-0359.2012v33n3p911

Nascimento, Q.; Marques, J. C.; Zambra, E. M.; Miranda, L. M. de. Perdas quantitativas no transporte curto de grãos de milho (Zea mays L.) em função de aspectos gerais de pós-colheita no norte do estado de Mato Grosso. Navus: Revista de Gestão e Tecnologia, v.6, p-60-71, 2016. https://doi.org/10.1590/S010069162011000400013

Nascimento, V. R. G.; Queiroz, M. R. de. Estratégias de aeração de milho armazenado: Temperatura e teor de água. Engenharia Agrícola, v.31, p.745-759, 2011.

Oliveira Neto, M. S. de; Reis, A. da C.; Stender, G. H. C.; Costa, W. O. da; Souza, C. G. de. Avaliação dos critérios de seleção de transportador e modais para o escoamento da safra de soja brasileira. Revista Produção e Desenvolvimento, v.1, p.14-30, 2015.

Ortiz, D.; Rocheford, T.; Ferruzzi, M. G. Influence of temperature and humidity on the stability of carotenoids in biofortified maize (Zea mays L.) genotypes during controlled postharvest storage. Journal of Agricultural and Food Chemistry, v.64, p.2727-2736, 2016. https://doi.org/10.1021/acs.jafc.5b05698

Paraginski, R. T.; Rockenbach, B. A.; Santos, R. F. dos; Elias, M. C.; Oliveira, M. de. Qualidade de grãos de milho armazenados em diferentes temperaturas. Revista Brasileira de Engenharia Agrícola e Ambiental, v.19, p.358-363, 2015. https://doi.org/10.1590/18071929/agriambi.v19n4p358-363

Sousa, D. M. G.; Lobato, E. Calagem e adubação para culturas anuais e semiperenes. In: Sousa, D. M. G.; Lobato, E. (ed.). Cerrado - Correção do solo e adubação. 2.ed. Brasília-DF: Embrapa Informação Tecnológica, 2004. p.283-315.

Stefanello, R.; Muniz, M. F. B.; Nunes, U. R.; Dutra, C. B.; Somavilla, I. Physiological and sanitary qualities of maize landrace seeds stored under two conditions. Ciência e Agrotecnologia, v.39, p.339-347, 2015. https://doi.org/10.1590/S1413-70542015000400004

Tsedaley, B.; Adugna, G. Detection of fungi infecting maize (Zea mays L.) seeds in different storages around Jimma, Southwestern Ethiopia. Journal of Plant Pathology \& Microbiology, v.7, p.1-6, 2016. https://doi.org/10.4172/2157-7471.1000338 